\title{
HTLV-1 Tax induces Th1 master regulator T-bet and thus IFN- $\gamma$ in CD4+CCR4+ T-cells of virus-associated myelopathy patients
}

\author{
Natsumi Araya', Tomoo Sato', Utano Tomaru², Ariella Coler-Reilly', Naoko Yagishita', Junji Yamauchi', \\ Atsuhiko Hasegawa ${ }^{3}$, Mari Kannagi ${ }^{3}$, Hisanao Akiyama ${ }^{4}$, Yasuhiro Hasegawa ${ }^{4}$, Katsunori Takahashi ${ }^{1}$, \\ Yasuo Kunitomo ${ }^{1}$, Yuetsu Tanaka ${ }^{5}$, Atae Utsunomiya ${ }^{6}$, Steven Jacobson ${ }^{7}$, Yoshihisa Yamano ${ }^{1 *}$
}

From 17th International Conference on Human Retroviruses: HTLV and Related Viruses

Trois Ilets, Martinique. 18-21 June 2015

The plasticity inherent to the CD4+ T cell differentiation program especially as it pertains to regulatory $\mathrm{T}$ (Treg) cells has been implicated in the pathogeneses of multiple inflammatory diseases. Human T-lymphotropic virus type 1 (HTLV-1) is thought to effect transcriptional changes in infected T cells via HTLV-1 Tax that can cause once suppressive CD4+CD25+CCR4+ Treg cells to lose FOXP3 expression and produce IFN- $\gamma$. We hypothesized that spawning of such inflammatory Th1like cells from infected CCR4+ T cells plays a key role in the pathogenesis of the neurodegenerative inflammatory disease HTLV-1-associated myelopathy/tropical spastic paraparesis (HAM/TSP). In this study, we demonstrated that Tax in cooperation with specificity protein $1(\mathrm{Sp} 1)$ boosts the expression of the Th1 master regulator $\mathrm{T}$ box transcription factor (T-bet/Tbx21) and consequently IFN- $\gamma$. We established the presence of abundant CD4+CCR4+ T cells co-expressing the Th1 marker CXCR3 and producing T-bet/Tbx21 and IFN- $\gamma$ in the CSF and spinal cord lesions of HAM/TSP patients. Finally, we tested treatments on ex vivo cell cultures from patients and found evidence that a therapy targeting CCR4+ T cells via antibody-dependent cellular cytotoxicity may represent a viable treatment option for HAM/TSP.

\section{Authors' details}

'Department of Rare Diseases Research, Institute of Medical Science,

St. Marianna University School of Medicine, Kawasaki, Japan. ${ }^{2}$ Department of

\footnotetext{
* Correspondence: yyamano@marianna-u.ac.jp

'Department of Rare Diseases Research, Institute of Medical Science,

St. Marianna University School of Medicine, Kawasaki, Japan

Full list of author information is available at the end of the article
}

Pathology, Hokkaido University Graduate School of Medicine, Sapporo, Japan. ${ }^{3}$ Department of Immunotherapeutics, Tokyo Medical and Dental University, Graduate School, Tokyo, Japan. ${ }^{4}$ Department of Neurology, St. Marianna University School of Medicine, Kawasaki, Japan. ${ }^{5}$ Department of Immunology, Graduate School of Medicine, University of the Ryukyus, Okinawa, Japan. ${ }^{6}$ Department of Hematology, Imamura Bun-in Hospital, Kagoshima, Japan. ${ }^{7}$ Viral Immunology Section, Neuroimmunology Branch, National Institutes of Health, Bethesda, MD, USA.

Published: 28 August 2015

\section{doi:10.1186/1742-4690-12-S1-P44}

Cite this article as: Araya et al.: HTLV-1 Tax induces Th1 master regulator T-bet and thus IFN- $\gamma$ in CD4+CCR4+ T-cells of virus-associated myelopathy patients. Retrovirology 2015 12(Suppl 1):P44.
Submit your next manuscript to BioMed Central and take full advantage of:

- Convenient online submission

- Thorough peer review

- No space constraints or color figure charges

- Immediate publication on acceptance

- Inclusion in PubMed, CAS, Scopus and Google Scholar

- Research which is freely available for redistribution

Submit your manuscript at www.biomedcentral.com/submit
() Biomed Central 